\title{
More or less (soft) law? The case of third country migration cooperation and the long-term effects of $E U$ preference for soft law instruments
}

\author{
Eleonora Frasca*
}

\begin{abstract}
Through a variety of examples, an appraisal of EU third-country informal cooperation on migration is provided to show that a preference towards softer instruments of cooperation has emerged. To illustrate the breadth and depth of such informal tools, four perspectives are adopted: first, a geographical one, which elucidates the reach of the EU action; second, a perspective related to the vastness and variety of the objectives pursued through informal cooperation; third, one which focuses on the role of funding in support of this action; and lastly, a perspective which examines the narrative framework of soft cooperation. This paper aims to assess whether and to what extent this trend reflects either a 'more' or 'less' law approach to third country migration cooperation in the EU. Through the lens of European soft law theory, the status of informal cooperation within the realm of soft law is examined. As the choice of 'more' or 'less' law is inherently political, the preference for alternative law-making methods can have an immense impact on the functioning of a legal system. Thus, some of the practical consequences produced by soft law in this field are presented, namely de-proceduralisation, de-formalisation and de-legalisation.
\end{abstract}

\section{Introduction: $E U$ third country informal cooperation and soft law}

The external dimension of European migration law has been one of the most active domains of quasi-law-making in recent years: a surge in soft cooperation between the European Union (EU) and third countries, which is informal in nature, has occurred. It includes areas such as border controls, return operations, international protection, and migration prevention. A working definition of 'soft cooperation' is an action which, despite its proclaimed nonbinding character, produces legal effects from the European Union to third countries. ${ }^{1}$

\footnotetext{
* PhD Researcher in EU Migration Law, Law Faculty, Université catholique de Louvain (UCLouvain, Belgium), Centre Charles De Visscher pour le droit international et européen (CeDIE), Member of Équipe droits européens et migrations (EDEM).

${ }^{1}$ I build on the definition used by Juan Santos Varas, 'Soft international agreements on migration cooperation with third countries" in Carrera, S., Santos Vara, J. and Strik, T. (Eds.), Constitutionalising the External Dimensions of Eu Migration Policies in Times of Crisis: Legality, Rule of Law and Fundamental Rights Reconsidered (UK: Edward Elgar 2019), p. 22: "Soft law is traditionally understood as non-legally binding norms that might have in practice legal relevance".
} 
Despite none of these activities qualifying as a regulatory act, their practical legal impact should not be underestimated. At first sight, it might be tempting to allocate this plethora of activities to the mere political sphere and reject any affinity to the legal field. However, when considering that such comprehensive, persuasive and geographically wide cooperation do not fit into the 'traditional' categories of purely legal or purely political acts and, because of the binding effects that it produces, it can be labelled 'soft law'.2

The strategy deployed by the EU and its Member States in the midst of the 'migration' crisis $^{3}$ is already demonstrating its long-term effects on European law-making. ${ }^{4}$ As soft law emerges in many forms and varieties, ${ }^{5}$ a more thorough analysis of informal cooperation is necessary from a legal perspective. Thus, this article will examine whether and to what extent this trend towards softer cooperation with third countries could be regarded as 'more' or 'less' law. ${ }^{6}$ After a brief discussion on the role of law in EU migration governance, an appraisal of EU third country informal cooperation as compared with formal cooperation is provided. More precisely, this article reflects on how informal cooperation belongs to the realm of soft law and on some of the practical consequences produced by soft law in this field.

\subsection{The role of law in EU migration governance}

Does a quantitative appraisal of law tell us something about the role of law in EU migration governance? How can a 'maximum' level and a 'minimum' level of law be envisaged? Hard law has been a powerful vehicle for the constitutionalisation of the European legal order which was, in principle, an experiment of international cooperation between States. ${ }^{7}$

\footnotetext{
${ }^{2}$ There is no unanimous definition of soft law and the very existence of soft law is controversial. It is often used as an umbrella term to describe a great variety of instruments, heterogenous in nature. Soft law instrument are not legally binding in the ordinary sense, but they are also not devoid of legal effects. See for instance: Anne Peters and Isabella Pagotto, 'Soft Law as a New Mode of Governance: A Legal Perspective' [28 February 2006], NEWGOV: New Modes of Governance.

${ }^{3}$ The terms European 'migration' crisis or 'refugee' crisis refer to the period of time between 2014 and 2016, characterised by a large number of migrants arrivals to Europe. For a diagnosis of the European 'migration' crisis in the sense of a crisis of European governance see: Jean-Yves Carlier, François Crépeau, Anna Purkey, 'From the European "Migration Crisis" to the Global Compact for Migration: A Political Transition Short on Legal Standards', McGill Journal of Sustainable Development, 16, 2020. See also: Geoff Gilbert, 'Why Europe Does Not Have a Refugee Crisis', (2015) 27 IJRL, 531.

${ }^{4}$ Hit by the COVID-19 health crisis, which has profoundly affected migration and mobility in and outside the European territory, the EU is now facing new challenges which European law can contribute to tackle.

${ }^{5}$ Kenneth W. Abbott and Duncan Sindal, 'Hard and Soft Law in International Governance' (2000) 54 International Organization 421.

${ }^{6}$ A note on terminology: in this paper, soft cooperation, informal cooperation, soft law, soft instruments are used as synonyms. This is the same for informalisation and softening of law. The terms are used interchangeably to describe this phenomenon, limitedly to the European external action on migration.

${ }^{7}$ European integration has been driven by the Court of Justice of the European Union, which has interpreted primary law in order to build the foundation of a supranational legal order, and by domestic courts, which have contributed to disseminate European law. The evolution of methods of law-making cannot be disentangled from the institutional context of the Union: the roles of the Council, the European Parliament, the European Commission and the Court of Justice of the European Union
} 
As for EU migration law, borders, visa and asylum legislation have been progressively embedded into the checks and balances of the European framework.

EU migration law - a field of shared competence - has been developed through time, in a diverse range of decision-making settings and with different degrees of formality. Notwithstanding, a periodic fluctuation between hard law and soft law can be observed. Two dynamics, among others, have gradually emerged.

From 1980-2010, Member States full competence on migration issues was progressively replaced by a shared competence and embedded into European framework for law-making. The Schengen and the Dublin systems both followed the logics of international law-making, namely ad hoc intergovernmentalism. Following Treaty reforms, further integration and progressive enlargement of the EU, hard legislative production has significantly increased in a gradual but steady process of 'Europeanisation' of migration law. ${ }^{8}$ The first decade of the new European Migration Law (2000 - 2010) has been therefore welcomed by legal scholars who observed, among other developments, this shift from discretion to law. ${ }^{9}$

During the last years, the European 'migration' crisis has affected the role of law in the management of migration movements, ${ }^{10}$ resulting in a shift from law to discretion. ${ }^{11}$ With the European Agenda on Migration, ${ }^{12}$ the need to regulate migration acquired political salience and yet it was not accompanied by progress in the form of hard law and most of the legislative production in this area is in deadlock. Subsequently, the EU adopted a more informal approach, which consists predominately of soft law. Since 2014, legislation based on Chapter 2 of Title V TFEU amounted to 24 legislative instruments. ${ }^{13}$

\footnotetext{
have changed significantly through time. The establishment of specialised agencies have been established and they have complexified the institutional landscape and the consequent accountability for European actions within and outside the EU.

8 Title IV: 'Visa, asylum, immigration and other policies linked to freedom of movement of the Amsterdam treaty has crystallised this process. See Jean-Yves Carlier, François Crépeau, 'Le droit européen des migrations: exemple d'un droit en movement?, Annuaire Français de Droit International (2011) LVII.

${ }^{9}$ Elspeth Guild, Paul Minderhoud, The First Decade of EU Migration and Asylum Law (Martinus Nijhoff, Leiden, The Netherlands 2012).

${ }^{10}$ Jean-Yves Carlier, François Crépeau, 'De la 'crise' migratoire européenne au pacte mondial sur les migrations : exemple d'un mouvement sans droit?' Annuaire français de droit international (2017) LXIII, 464.

${ }^{11}$ Paul James Cardwell, “Tackling Europe's Migration "Crisis" through Law and "New Governance"” (2018) 9 Global Policy 67.

${ }^{12}$ Commission, 'Managing the refugee crisis: State of Play of the Implementation of the Priority Actions under the European Agenda on Migration' COM(2015) 240 final.

${ }^{13}$ The vast majority of those consist of amendments of existing regulations (e.g. regulation listing the third countries whose nationals must be in possession of visas when crossing the external borders: Regulation (EU) 2018/1806 of the European Parliament and of the Council of 14 November 2018 listing the third countries whose nationals must be in possession of visas
} 
A quantitative analysis of law might also reveal qualitative observations. ${ }^{14}$ If it is not questionable that the choice of 'more' or 'less' law is inherently political - because only in the political arena can the opportunity to legislate or not be established - the preference for alternative law-making methods can have a huge impact on the functioning of a legal system. ${ }^{15}$ Migration law is therefore a privileged angle of observation of such changes in regulatory techniques. ${ }^{16}$

\subsubsection{Law in the internal dimension: asylum, solidarity, and fair sharing of responsibility}

In the field of asylum, no hard law has been adopted at the EU level in the last five years, despite multiple attempts to legislate driven by the European Commission ${ }^{17}$ which is undergoing political marginalization. ${ }^{18}$ As confirmed by the state of the asylum 'package' reform, ${ }^{19}$ presently in deadlock, 'more' law is currently a utopia. Law-making in this field is

when crossing the external borders and those whose nationals are exempt from that requirement PE/50/2018/REV/1 OJ L 303, 28.11.2018, p. 39-58), funds (e.g. Asylum, Migration and Integration Fund: Regulation (EU) No 516/2014 of the European Parliament and of the Council of 16 April 2014 establishing the Asylum, Migration and Integration Fund, amending Council Decision 2008/381/EC and repealing Decisions No 573/2007/EC and No 575/2007/EC of the European Parliament and of the Council and Council Decision 2007/435/EC IO L 150, 20 May 2014, 168-194), and reforms of the European Border Coast Guard (Regulation (EU) 2019/1896 of the European Parliament and of the Council of 13 November 2019 on the European Border and Coast Guard and repealing Regulations (EU) No 1052/2013 and (EU) 2016/1624, OJ L 295, 14.11.2019, p. 1-131) or the Visa Code (Regulation (EU) 2019/1155 of the European Parliament and of the Council of 20 June 2019 amending Regulation (EC) No 810/2009 establishing a Community Code on Visas (Visa Code) PE/29/2019/REV/1 [2019] OJ L 188 2554).

${ }^{14}$ This reflection was fostered by the research project "GLOBMIG. New approaches to understanding \& modeling global migration trends" and particularly by the Working Paper by Eleonora Frasca and Francesco Gatta titled "Changing trends and dynamics of EU Migration Law and Governance: a critical assessment of the evolution of migration legislation and policy in Europe' (forthcoming).

${ }^{15}$ Natalino Irti, Un diritto incalcolabile (Giappichelli, 2016), p. 191.

${ }^{16}$ Debates on the rule of law, law and governance, law and politics, they all contribute to this field of analysis. See, among others: Francesco Luigi Gatta, 'Migration and the Rule of (Human Rights) Law: Two 'Crises' Looking in the Same Mirror' (2019) 15 CYELP 99.

${ }^{17}$ Commission, 'Completing the reform of the Common European Asylum System: towards an efficient, fair and humane asylum policy', Brussels, 13 July 2016, Press release. This article was written before the European Commission released the Communication on the new Pact on Migration and Asylum, so it does not take into account the reforms proposed therein. However, many considerations written in this section can be applied to the new reform.

18 Jean-Yves Carlier, François Crépeau, Anna Purkey, 'From the European "Migration Crisis" to the Global Compact for Migration: A Political Transition Short on Legal Standards' McGill Journal of Sustainable Development, 16, 2020.

${ }^{19}$ The Commission has presented six legislative proposal on asylum reforms: Proposal for a Regulation of the European Parliament and the Council establishing a common procedure for international protection in the Union and repealing Directive 2013/32/EU; Proposal for a Regulation of the European Parliament and Council on standards for the qualification of thirdcountry nationals or stateless persons as beneficiaries of international protection, for a uniform status for refugees or for persons eligible for subsidiary protection and for the content of the protection granted and amending Council Directive 2003/109/EC of 25 November 2003 concerning the status of third-country nationals who are long-term residents; Proposal for a Directive of the European Parliament and of the Council laying down standards for the reception of applicants for international protection (recast); Proposal for a Regulation of the European Parliament and the Council establishing a Union Resettlement System and amending Regulation (EU) No 516/2014 of the European Parliament and the Council; Proposal for a Regulation of the European Parliament and of the Council establishing the criteria and mechanisms for determining the Member State responsible for examining an application for international protection lodged in one of the Member States by a third country 
currently on hold obstructed by the pursuit of national interests and reaffirmation of state sovereignty.

The lack of consensus between Member States, fueled by national governments' disputes over solidarity, conflicts with the Commission's urge for more law in two ways. On the one hand, the effect of the crisis could have been mitigated by using existing legal instruments, such as the Temporary Protection Directive. ${ }^{20}$ Despite the availability of this option, all endeavors to elaborate common solutions to the issue of responsibility-sharing have been placed outside legal boundaries (e.g. the Malta declaration of intent). ${ }^{21}$

On the other hand, a bias towards emergency measures arose to correct, at least temporarily, the pitfalls of the Common European Asylum System (CEAS). Pursuant to Article 78(3) TFEU, a broad margin of discretion has been given to the Council which adopted measures such as the relocation decisions. ${ }^{22}$ Through a placebo effect, those measures have temporarily alleviated the pressure of the Dublin rules on Greece and Italy, and consequently the 'flaws of their asylum systems'. ${ }^{23}$ However, the relocation schemes have been stubbornly opposed in some countries. The Court of Justice of the European Union (CJEU) confirmed that a binding relocation mechanism was necessary 'to give effect to the principle of solidarity and

national or a stateless person (Recast); Proposal for a Regulation of the European Parliament and of the Council on the European Union Agency for Asylum and repealing Regulation (EU) No 439/2010.

For a discussion of the legacy of this reform: Kris Pollet, 'All in vain? The fate of EP positions on asylum reform after the European elections' (European Migration Law blog, 23 May 2019) < http://eumigrationlawblog.eu/all-in-vain-the-faith-ofep-positions-on-asylum-reform-after-the-european-elections/> accessed 25 June 2020; Salvo Nicolosi, 'Unfinished Business: The European Parliament in the negotiations for reform of the Common European Asylum System' (EU Law Analysis, 23 June 2019) < http://eulawanalysis.blogspot.com/2019/06/unfinished-business-european-parliament.html> accessed 25 June 2020.

${ }^{20}$ M Den Heijer, JJ Rijpma, T Spijkerboer, 'Coercion, Prohibition, and Great Expectations: The Continuing Failure of the Common European Asylum System’ Common Market Law Review 53(2016), pp. 607-642.

${ }^{21}$ Joint declaration of intent on a controlled emergency procedure. For a legal analysis see: Sergio Carrera, Roberto Cortinovis, The Malta declaration on SAR and relocation: A predictable EU solidarity mechanism? (CEPS Policy Contribution, 11 October 2019); Eleonora Frasca, Francesco Luigi Gatta 'The Malta declaration on search \& rescue, disembarkation and relocation: Much Ado about Nothing' (EU Migration Law Blog, 3 March 2020), <http://eumigrationlawblog.eu/the-maltadeclaration-on-search-rescue-disembarkation-and-relocation-much-ado-about-nothing/> accessed 1 July 2020.

${ }^{22}$ Council, Decision (EU) 2015/1523 of the Council 14 September 2015 establishing provisional measures in the area of international protection for the benefit of Italy and of Greece [2015] OJ L239 146 -156 and Decision 2015/1601 of 22 September 2015 establishing provisional measures in the area of international protection for the benefit of Italy and Greece [2015] OJ L248 80-94.

${ }^{23}$ The concept of 'systemic flaws' comes from the CJEU judgment of 21 December 2011, NS, joined cases C-411/10 and C493/10, EU:C:2011:865. In the NS case, the Court ruled on transfers under the 'Dublin II' regulation (Regulation n. 343/2003) clarifying that the transfers under the Dublin Regulation would be incompatible with Article 4 of the EU Charter of Fundamental Rights 'if there are substantial grounds for believing that there are systemic flaws (or deficiencies) in the asylum procedure' (\$86) in the State of transfer. The notion of "systemic flaws" was consolidated in Article 3(2) of the Dublin III Regulation recast (Regulation n. 604/2013). 
fair sharing of responsibility'. ${ }^{24}$ In the second 'relocation' judgment, Advocate General Sharpston emphasized that the principles of the rule of law, the duty of sincere cooperation and solidarity are three important strands of the EU legal order, which are put in jeopardy by those Member States who fail to comply with European law. ${ }^{25}$

The current state of asylum law-making, which goes beyond the scope of this analysis, leans towards the direction of less secondary law, as compared to the steady process of Europeanisation of asylum law observed until 2013. ${ }^{26}$ However, the pre-eminence of the principle of solidarity under Article 80 TFEUwas reiterated in a series of judgments by the European Court of Justice as well as Advocate Generals, ${ }^{27}$ and which could be regarded as a more primary law trend. ${ }^{28}$ Overall, for asylum matters, it is not a question or 'more' or 'less' law, but of fairer rules, with respect both to the human rights of migrants and to solidarity in the spirt of sincere cooperation with Member States located at the external borders.

\subsubsection{Law in the external dimension: informal EU third country cooperation}

The crisis of the internal dimension of migration has led to an over-focus on the external dimension. While no hard law can be observed in this field in recent times, ${ }^{29}$ the EU inaugurated a new fashion of cooperation with countries that were deemed key players in terms of migration control and migrant containment. Soft cooperation did not come abruptly: it has been progressively built by the EU. However, during the 'migration' crisis, the use of soft

\footnotetext{
${ }^{24}$ Court of Justice of the European Union, Case C-643/15 Slovakia and Hungary v European Union Council [2017] EU:C:2017:631, §§252-253.

${ }^{25}$ Opinion of Advocate General Sharpston delivered on 31 October 2019, Case C-715/17 European Commission v Republic of Poland Case, C-718/17 European Commission v Republic of Hungary, Case C-719/17 European Commission v Czech Republic, EU:C:2019:917. In this case, the CJEU reiterated the binding character of the relocation mechanism, ruling that Hungary, Poland and the Czech Republic had failed to comply with the relocation obligation under EU law For a caselaw commentary of this judgment see: Eleonora Frasca, Francesco Luigi Gatta, 'Rebel rebel, how could they know? The boundless imagination of Poland, Hungary and the Czech Republic in opposing the relocation mechanism' (Cahier de l'EDEM, June 2020) $<$ https://uclouvain.be/fr/instituts-recherche/juri/cedie/actualites/court-of-justice-of-the-european-union-judgment-of-2april-2020-joined-cases-c-715-17-c-718-17-and-c-719-17-ecli-eu-c-2020-257.html $>$ accessed 1 July 2020; Niel Kirst, 'Protecting the Formal Rule of Law in the EU's Asylum Policy: The CJEU's Judgment on the Asylum Relocation Mechanism' (EU Law Analysis blog, 20 June 2020) <http://eulawanalysis.blogspot.com/2020/06/protecting-formal-rule-of-law-ineus.html>, accessed 3 July 2020.

${ }^{26}$ For a discussion of the 'refugee' crisis and of the failed reform of European asylum law see Vincent Chetail, 'Looking beyond the Rhetoric of the Refugee Crisis: The Failed Reform of the Common European Asylum System' European Journal of Human Rights (2016) pp. 584-602.

${ }^{27}$ See, for instance, Opinion of Advocate General Wathelet delivered on 25 July 2018, Case C-163/17, Abubacarr Jawo v Bundesrepublik Deutschland, EU:C:2018:613.

${ }^{28}$ Article 80 TFEU: 'The policies of the Union set out in this Chapter and their implementation shall be governed by the principle of solidarity and fair sharing of responsibility, including its financial implications, between the Member States. Whenever necessary, the Union acts adopted pursuant to this Chapter shall contain appropriate measures to give effect to this principle'.

${ }^{29}$ Or only in limited exceptions, e.g.: EU Readmission agreements with Turkey (2014) and Azerbaijan (2014).
} 
instruments found its uppermost legitimation. ${ }^{30}$ On the one hand, the external dimension of European migration law has always been permeated by a certain degree of 'softness': dialogues, ${ }^{31}$ regional processes ${ }^{32}$ and other types of informal arrangements were put in place already before the migration crisis. ${ }^{33}$ This strategy responds to the alignment of migration, security and development objectives. ${ }^{34}$ Firstly, it comprises 'the fight against irregular migration' which consists of increasing return while preventing migration from certain third countries. Secondly, it encompasses the long-term objective of 'tackling the root causes of migration' in view of development which is a goal that neglects the conspicuous body of literature showing that more development leads to more migration. ${ }^{35}$

From a quantitative point of view, informal cooperation has been increasingly integrated into other policy fields and mainstreamed in agreements, sometimes to the detriment of competing policy objectives. ${ }^{36}$ In the field of foreign policy, greater use of 'issue linkage ${ }^{37}$ has resulted in migration clauses often being included in agreements that are not, in principle,

\footnotetext{
${ }^{30}$ Loïc Azoulai and Karin de Vries (eds), EU Migration Law: Legal Complexities and Political Rationales (1 ${ }^{\text {st }}$ ed, Oxford University Press 2014).

${ }^{31}$ For instance: the High-Level Dialogues on Migration, the Africa-EU Migration and Mobility dialogue, the Valletta Summit in November 2015.

${ }^{32}$ Dialogues with a sub-regional focus, known as 'processes', such as the Khartoum and Rabat processes, respectively focusing on West Africa and the Horn of Africa.

${ }^{33}$ In this respect, there is some continuity with previous modalities of cooperation. See, for instance, Natasja Reslow, 'Old wine in new wineskins? The EU's Migration Partnership Framework' (Web publication/site, 2017, Junge Wissenschaft im Öffentlichen Recht e.V.) <https://cris.maastrichtuniversity.nl/en/publications/old-wine-in-new-wineskins-the-eus-migrationpartnership-framework>

${ }^{34}$ These same 'old' objectives were identified in: 1) the Tampere Conclusions (Council of the European Union, Presidency Conclusions, Tampere European Council, 15-16 October 1999); 2) The Global Approach to Migration (European Council, Note from the Presidency on a Global Approach to Migration: Priority Actions focusing on Africa and the Mediterranean, 15744/05, Brussels, 13 December 2005) and 3) the Global Approach to Migration and Mobility (Commission, 'The Global Approach to Migration and Mobility', COM(2011)0743 final). For an analysis of development in EU migration law and policy twenty years after the Tampere Conclusions see: P De Bruycker, M. De Somer M, J-L De Brouwer (Eds.) From Tampere 20 to Tampere 2.0: Towards a new European consensus on migration (European Policy Centre, 2019).

${ }^{35}$ Hein de Haas, 'Turning the Tide? Why Development Will Not Stop Migration' Development and Change 38(2007)5 pp. $821-44$

${ }^{36}$ E.g. on blurring between migration objectives and EU neighbourhood ones see: Sara, Poli, 'The Integration of Migration Concerns into EU External Policies: Instruments, techniques and legal problems' European Papers 5 (2020) 1, pp. 71-94; Marion Panizzon 'The Global Migration Compact and the Limits of 'Package Deals' for Migration Law and Policy' What is a compact? Migrants' Rights and State Responsibilities Regarding the Design of the UN Global Compact for Safe, Orderly and Regular Migration, Raoul Wallenberg Institute of Human Rights and Humanitarian Law, pp. 17-26.

37 'Issue linkage' happens when two or more issues are bargained in the same international cooperation instruments, which motivate States to comply.
} 
regulating migration. ${ }^{38}$ In the field of the Common Security and Defense policy, migration control objectives have been mainstreamed into military operations. ${ }^{39}$

From a qualitative point of view, in the discourse of the European institutions, informal non-binding measures were claimed to be the most appropriate 'to halt the human misery created by those who exploit migrants'. ${ }^{40}$ This language was crystallized in a series of communications from the European Agenda on Migration. ${ }^{41}$ In particular, political programming in this field is nurtured by documents such as the Action Plan on Return, ${ }^{42}$ the EU-Turkey Joint Action Plan, ${ }^{43}$ the Valletta Action Plan, ${ }^{44}$ the EU Action Plan against Migrant Smuggling, ${ }^{45}$ and the new Migration Partnership Framework, which all have no legal value. ${ }^{46}$

This phenomenon can be regarded under two angles: one is 'hyper-legalization', intended as the increase in number of soft law instruments - to minimalize the need for hard law - with a self-referential nature. 'Hyper' means 'a surge in quantity' while 'legalization', as opposed to 'legislation', means attributing legal effects to acts that are, in theory, deprived of any legal effects. ${ }^{47}$ The other angle is that of 'de-legalization', which consists in the softening of hard law into soft law, or in the transformation of hard law into non-legal norms. ${ }^{48}$

\footnotetext{
${ }^{38}$ E.g. agreements on trade or development. Emblematic of this is the case of the EU-Jordan Compact, see Marion Panizzon, 'Trade-for-Refugee Employment: Nexing for Deterrence or Development in the EU-Jordan Compact?' Sergio Carrera and others (eds), EU External Migration Policies in an Era of Global Mobilities: Intersecting Policy Universes (Brill Nijhoff 2018); Sandra Lavenexm Flavia Jurje, 'Issue-Linkage in International Migration Governance: Trade Agreements as Venues for "Market Power Europe"?' (2014) 52 JCMS 320-336.

39 The previous European legislature has been characterised by a stronger and strengthened involvement of the European External Action Service (EEAS), including the High Representative of the Union for Foreign Affairs and Security Policy, in migration matters. See, for instance, EEAS, 'The European Union's partnership with the G5 Sahel countries', 180618_6, Factsheets.

${ }^{40}$ Commission, 'A European Agenda on Migration', Brussels 13 May 2015, COM(2015) 240 final.

${ }^{41}$ Ibidem.

${ }^{42}$ Commission, 'EU Action Plan on return', Communication, Brussels, 9 September 2015, COM(2015) 453 final.

${ }^{43}$ Commission, 'EU-Turkey Joint Action Plan', Press release, 15 October 2015.

${ }^{44}$ Valletta Summit, 11-12 November 2015, Political Declaration.

${ }^{45}$ Commission, EU Action Plan against migrant smuggling (2015 - 2020), Brussels, 27 May 2015, COM(2015) 285 final.

${ }^{46}$ Commission, 'Communication on establishing a new Partnership Framework with third countries under the European Agenda on Migration' COM(2016) 385 final. For an analysis see: Céline Bauloz, 'The EU Migration Partnership Framework: an External Solution to the Crisis?' (EU Migration Law Blog, 31 January 2017) < http://eumigrationlawblog.eu/the-eumigration-partnership-framework-an-external-solution-to-the-crisis/> accessed 2 July 2020.

47 Elaine Fahey, 'Hyper-legalisation and delegalisation in the AFSJ: on contradictions in the external management of EU migration' S. Carrera, J. Santos Vara, T Strik (Eds.), Constitutionalising the External Dimensions of Eu Migration Policies in Times of Crisis: Legality, Rule of Law and Fundamental Rights Reconsidered (UK: Edward Elgar 2019), pp. 116-134.

${ }^{48}$ Fabien Terpan, 'Soft Law in the European Union-The Changing Nature of EU Law: Soft Law in the European Union' (2015) 21 European Law Journal, p. 90. By providing examples from EU environmental, employment and social policy, the author explains that because these areas are subject to hybridity (both hard and soft measures coexist), there might be developed a preference for norms less constraining upon Member States.
} 
While the adoption of the New York Declaration for Refugee and Migrants signaled a need to discuss a framework for migration cooperation at the global level, ${ }^{49}$ European States demonstrated fragmentation and short-sightedness on how to envisage and organize such cooperation. The negotiations of the Global Compact for Migration, a soft law instrument of historical significance, ${ }^{50}$ are a good indicator of such divisions. While the European Commission wished to adopt a unified European approach in negotiations, ${ }^{51}$ the fragility of EU representation in migration matters rapidly emerged. ${ }^{52}$ The lack of consensus among Member States had the effect of decreasing the role of hard law in migration governance. ${ }^{53}$

For this reason, the external dimension of migration law has been a laboratory for alternative regulatory techniques. Some scholars describe this passage - albeit not unique to the migration field ${ }^{54}$ - as a shift from government to governance, ${ }^{55}$ which resulted in more soft law and less hard law. Against this backdrop, the second section makes a descriptive appraisal of EU third country informal cooperation as compared with formal cooperation. The third section reflects on how informal cooperation belongs to the realm of soft law. By way of conclusion, the fourth and last section pinpoints some of the practical consequences produced by soft law in this field.

\section{Informal vs formal EU cooperation with third countries}

\footnotetext{
${ }^{49}$ UNGA, 'New York Declaration for Refugees and Migrants' Res 71/1 (19 September 2016) UN doc A/RES/71/1. The United Nations General Assembly adopted the New York Declaration for Refugees and Migrant, a landmark political declaration directed at improving the way the international community responds to large movements of refugees and migrants, which contains a set of commitments by States to strengthen and enhance mechanisms to protect people on the move. The Declaration envisages the adoption of two Global Compacts, the Global Compact on Refugees (GCR) and the Global Compact for Safe, Orderly and Regular Migration (GRM) which are the first ever attempts to establish a framework for cooperation and dialogue, at the global level, to "facilitate migration".

${ }^{50}$ The non-binding nature of the Global Compact is affirmed in its text. UN General Assembly (UNGA), 'Global Compact for Safe, Orderly and Regular Migration' (19 December 2018) UN Doc A/RES/73/195, para 7: "This Global Compact presents a non-legally binding, cooperative framework that builds on the commitments agreed upon by Member States in the New York Declaration for Refugees and Migrants. It fosters international cooperation among all relevant actors on migration, acknowledging that no State can address migration alone, and upholds the sovereignty of States and their obligations under international law".

${ }^{51}$ Commission, 'Commission Proposal for Council Decisions Authorizing the Commission to Approve, on behalf of the Union, the Global Compact for Safe, Orderly and Regular Migration in the Area of Immigration Policy' COM(2018)168 final.

52 If Hungary, Austria, Bulgaria, Latvia decided not to endorse the Global Compacts - alleging that their national security interests would be undermined - several countries, such as Belgium, Slovakia and Italy, underwent political crisis at the moment of its adoption. Other countries, such as Denmark, Malta, the Netherlands and the UK, have adopted sceptical statements as regard the legal binding effect of the instrument. Although they voted in favour of the Global Compact, they reaffirmed their national sovereignty in migration matters.

${ }^{53}$ Ibidem, para 15(c): 'the Global Compact reaffirms the sovereign right of States to determine their national migration policy and their prerogative to govern migration within their jurisdiction, in conformity with international law'.

${ }^{54}$ For an example in the monetary policy field, see Nicole Scicluna, 'Integration through the Disintegration of Law? The ECB and EU Constitutionalism in the Crisis' (2018) 25 Journal of European Public Policy, pp. 1874-1891

${ }^{55}$ Roberto Bin, 'Soft law, no law', in A. Somma (a cura di), Soft law e hard law nelle società postmoderne, pp. 33-38.
} 
Both the EU and its Member States increasingly revert to soft law arrangements to design and implement migration policies. It could be argued that the development towards informalization is another manifestation of the rise of sovereignty claims. The need to act 'urgently' often justifies the choice of non-legally binding measures and therefore the absence of legal formalism. Acting outside the scope of the legislative process or without complying with legal requirements, Member States' too encourage informalization; soft national practices support and lead to the informalization of EU law and this creates 'an indistinct vicious cycle and feedback loop' ${ }^{56}$ to the extent that soft law at the EU level is incentivized and mirrored by soft law at the Member States level. ${ }^{57}$

The ultimate goal of soft cooperation is the fight against irregular migration, made up of several different components: preventing migratory pressure 'at source', installing any sorts of physical and digital border controls and migration prevention campaigns, and increasing third country national return rates. ${ }^{58}$ For migrants with international protection needs, the goal is to prevent their arrival or to filter the few who are eligible for resettlement to the EU from the bigger cohort.

Many informal instruments, such as the EU-Turkey statement or the Migration Compacts, serve multiple objectives at the same time. ${ }^{59}$ For instance, the Commission states that these agreements are intended:

'to give a new impetus to resettlement policy, but would also improve the reception capacities of third countries with a view to the implementation of return operations .60

\footnotetext{
${ }^{56}$ Federico Casolari, 'The Unbearable "Lightness" of Soft Law: On the European Union's Recourse to Informal Instruments in the Fight Against Illegal Immigration' in Emmanuelle Bribosia and others (eds), L'Europe au kaléidoscope. Liber Amicorum Marianne Dony (Editions de l’Université de Bruxelles 2019), p. 463.

${ }^{57}$ Elisa Olivito, 'The Constitutional fallouts of border management through informal and deformalized external action: the case of Italy and the EU' Diritto, Immigrazione e Cittadinanza, (2020)2, pp. 112-137.

${ }^{58}$ Valsamis Mitsilegas, 'Extraterritorial Immigration Control, Preventive Justice and the Rule of Law in Turbulent Times: Lessons from the Anti-Smuggling Crusade' J. Santos Vara, S. Carrera and T. Strik (eds.), Constitutionalising the External Dimension of EU Migration Policies in Times of Crisis: Legality, Rule of Law and Fundamental Rights Reconsidered, (Edward Elgar, 2018).

${ }^{59}$ Lisa Haferlach, Dilek Kurban, 'Lessons Learnt from the EU-Turkey Refugee Agreement in Guiding EU Migration Partnerships with Origin and Transit Countries' Global Policy (2017) 8, pp. 85-93.

${ }^{60}$ Commission, 'Communication on establishing a new Partnership Framework with third countries under the European Agenda on Migration' COM(2016)385 final.
} 
Providing a variety of examples of soft instruments, this section makes a descriptive appraisal of EU third-country informal cooperation on migration. Four perspectives are illustrated: firstly, a geographical perspective which elucidates the reach of the EU action; secondly, a perspective related to the vastness and variety of the objectives pursued through informal cooperation in different contexts; ${ }^{61}$ thirdly, one which focuses on the role of funding in support of this action; and lastly, a perspective which examines the narrative used to frame and support soft cooperation. All these perspectives can be compared with what would, instead, be formal cooperation.

\subsection{A matter of geography: the reach of the EU external action on migration}

A novel element in the EU's actions on migration has been its geographic expansion. ${ }^{62}$ The EU has begun engaging with neighbor countries in an open, far-reaching, and confrontational way (e.g., Turkey), but also with countries extremely far from the EU external borders (e.g., Ethiopia, Senegal, Jordan). Although each third country with whom the EU cooperates has its own 'profile', both from a geopolitical perspective and from a migrant population demographics, there are patterns that are followed by the EU when cooperating with third countries. That is why the EU refers to 'tailored-made' solutions. ${ }^{63}$

Some cooperation concerns countries which host large refugee population, both at the doors of Europe, such as Turkey, and far from Europe's doors, such as Ethiopia. A second type of cooperation concerns countries whose nationals are likely to reach Europe irregularly because their legal mobility is highly restricted by visa rules and they figure among the top nationalities of irregular arrivals to the EU (e.g., Afghanistan, Bangladesh, Nigeria). A third country profile concerns those countries where migrants transit before reaching the EU (e.g., Morocco, Niger, Libya).

Overall, EU third country cooperation on migration has ranged from highly formalized to informal cooperation. In the context of the European Neighborhood Policy, and particularly with the Eastern Neighborhood, the EU and Member States have pursued a policy of

\footnotetext{
${ }^{61}$ For a discussion on how border controls and access to asylum are intertwined see Violeta Moreno-Lax, Accessing Asylum in Europe Extraterritorial Border Controls and Refugee Rights under EU Law (Oxford University Press, 2017, Oxford, UK). ${ }^{62}$ The boundaries of the external dimension of migration policy have gradually shifted from the EU's Eastern and Southern neighbourhood to sub-Saharan Africa and the Middle East.

${ }^{63}$ Commission, 'Communication on establishing a new Partnership Framework with third countries under the European Agenda on Migration' COM(2016)385 final, pp. 5-6. See Annelies Zoomers, Femke van Noorloos, Ilse van Liempt 'Will tailor-made migration deals help to solve the European migration 'crisis'?' Dina Siegel \& Veronika Nagy (Eds.) The Migration Crisis. Criminalization, Security and Survival. (Eleven International Publishers, 2018) pp.105-130.
} 
assimilation in the form of visa facilitation agreements linked to EU readmission agreements, those being the two main legal instruments deployed for migration cooperation. ${ }^{64}$ The first 'formalization' period occurred between 2000 and 2014, when the Commission obtained its first negotiating mandate, and when the latest EU readmission agreements (EURAs) were concluded with Cape Verde, ${ }^{65}$ Azerbaijan, ${ }^{66}$ and Turkey. ${ }^{67}$ The majority of EURAs have been stipulated with a broadly conceived Eastern European neighborhood. ${ }^{68}$ There has been little place for soft law arrangements, in view of it leading to hard law. Easing the tight visa regime, de facto, has allowed, through time, circular mobility of those third country nationals to the EU, eventually leading to visa exemption or liberalization.

The example of Moldova is illustrative of the requirement that a third country intending to cooperate with the EU on migration, must sign an EURA as only afterwards will its nationals (possibly) be able to benefit from a visa suspension mechanism. This mechanism will only be implemented if the third country is willing and does harmonize its national visa policy with the Schengen policy. ${ }^{69}$ In other words, in order to benefit from visa liberalization, third countries agree to adopt visa rules stemming from the EU legal order. ${ }^{70}$

Despite attempts to negotiate and conclude readmission agreements with countries from the immediate southern neighborhood, no consensus has been found between parties. ${ }^{71}$ Because of the obstacles to conclude readmission agreements and obstructionism from

\footnotetext{
${ }^{64}$ The legal basis to conclude EURAs is Article $79 \S 3$ TFEU following the procedure of Article 218 TFEU. The Treaty of Amsterdam gave the EU the explicit competence to make agreements 'with third countries for the readmission to their countries of origin or provenance of third-country nationals who do not or who no longer fulfil the conditions for entry, presence or residence in the territory of one of the Member States'.

${ }^{65}$ The only African country with whom the EU has concluded such agreement. Agreement between the European Union and the Republic of Cape Verde on the readmission of persons residing without authorisation OJ L 282, 24.10.2013, p. 15-34.

${ }^{66}$ Agreement between the European Union and the Republic of Azerbaijan on the readmission of persons residing without authorisation OJ L 128, 30.4.2014, pp. 17-42.

${ }^{67}$ Agreement between the European Union and the Republic of Turkey on the readmission of persons residing without authorisation OJ L 134, 7.5.2014, pp. 3-27.

${ }^{68}$ E.g. Serbia, Montenegro, Albania, Ukraine, but also Georgia, Moldova, etc.

${ }^{69}$ This example is explained by Lena Laube, 'The Relational Dimension of Externalizing Border Control: Selective Visa Policies in Migration and Border Diplomacy' Comparative Migration Studies (2019) 7, pp. 29-51. The author investigates the concept of 'border diplomacy' and provides examples of countries (Moldova, Morocco and Turkey), which use migration law as a foreign policy tool in different ways and with different outcomes.

${ }^{70}$ It could be argued that this is a case of legal transplant: the visa rules of the EU neighbours are absorbed by the EU legal order, informally, but de facto enlarging the Schengen legal space.

${ }^{71}$ Negotiations with Morocco have been on and off for the last twenty years. The example of Morocco is widely commented in legal and political science doctrine: Tasnim Abderrahim, 'A tale of two agreeements: EU migration cooperation with Morocco and Tunis' 41 (PapersIEMed, May 2019) pp 7-38; Sergio Carrera, Jean-Pierre Cassarino, Nora El Qadim, Mehdi Lahlou and Leonhard den Hertog, 'EU-Morocco Cooperation on Readmission, Borders and Protection: A model to follow?' CEPS N. 87/January 2016; Nora El-Qadim Nora, 'Le gouvernement asymétrique des migrations. Maroc/Union européenne' 2015, Paris, Dalloz; Kevin Kaiser, 'EU-Morocco negotiations on a readmission agreement: obstacles to a successful conclusion' (EU Diplomacy Paper, 07/2019, College of Europe).
} 
Member States who wished to pursue bilateral cooperation, the EU started softening migration cooperation with third countries as a solution to re-balance the weight of the EU in favor of bilateralism. ${ }^{72}$ The so-called Mobility Partnerships are the first generation of EU instruments for informal cooperation. Under this soft instrument $(2008-2013),{ }^{73}$ the EU performed an 'umbrella' function while Member States were free to take part in the partnership, with the consequence that their participation rates were variable and low. ${ }^{74}$

In 2016, five Migration Compacts were stipulated with Niger, Nigeria, Mali, Senegal and Ethiopia. Those instruments can be considered the second generation of Mobility Partnerships, ${ }^{75}$ but while Mobility Partnerships were open to Member States participation, Migration Compacts were backed up by direct political pressure in the form of a higher involvement of Member States diplomacy, funds and incentives for cooperation.

Overall, the EU is increasingly interested in initiating and promoting migration cooperation, although only at its own terms and priorities. ${ }^{76}$ Not only the reach of the EU external action on migration is geographically wide, but also rich in terms of objectives pursued through soft cooperation.

\subsection{A matter of content: soft instruments serve many and varied objectives}

Informal migration cooperation with third countries pursues a great variety of objectives. In the words of the Commission:

"the short-term objectives are to save lives in the Mediterranean Sea, increase rates of return to countries of origin and transit, and enable migrants and refugees to stay close to home avoiding taking dangerous journeys. Immediate action with partners will focus on improving the legislative and institutional framework for migration and capacity building on border and migration

\footnotetext{
${ }^{72}$ Jean-Pierre Cassarino, Mariagiulia Giuffré, 'Finding Its Place In Africa: Why has the EU opted for flexible arrangements on readmission?' (FMU Policy Brief No. 01/2017, 1 December 2017)

${ }^{73}$ Mobility Partnership were stipulated with Cape Verde, Moldova, Georgia, Armenia, Morocco, Azerbaijan, Tunisia, Jordan, and Belarus.

${ }^{74}$ The most involved Member States were those who had already developed international relations with third countries in the field of migration (Portugal, Spain, France, United Kingdom) and wanted to ensure consistency with previous bilateral agreements. See for instance: Natasja Reslow, Partnering for mobility? Three-level games in EU external migration policy. 2013, Datawyse / Universitaire Pers Maastricht.

75 The list of potential candidates also included countries such as Jordan, Lebanon, and Afghanistan.

${ }^{76}$ Sara Poli, Claudia Cinelli 'Mobility and legal migration in the context of the European Neighbourhood Policy: What role for the European Union?’ Revista de Derecho Comunitario Europeo (2017)58 pp. 979-1005.
} 
management, including providing protection to refugees. [...] Long-term objectives include the efforts to address the root causes of irregular migration and provide capacity." 77

To illustrate the vastness of the European action in this field, examples can be taken for each of those above-mentioned strands.

\subsubsection{Return and readmission to third countries}

While EU readmission agreements represents the prototype of highly formalized agreements in the field of return, atypical informal arrangements have also emerged in this field.

Informal agreements tend to fall outside the scope of EU law-making procedures, since they are deliberately negotiated and concluded without complying with the procedural rules set by Article 218 TFEU. Consequently, only the Council, the Member States or the European External Action Service (depending on the content of cooperation) can pursue their interests outside the European constitutional framework. Readmission, which was meant to become an exclusive competence, is still subject to hybridity - the co-existence of EU and Member States bilateral agreements, formal and informal.

The EU-Turkey statement is, by large, the informal agreement which has the most evident impact from the legal point of view, especially on the migrants' fundamental rights. The statement's compliance with international and European law, its controversial legal nature and ambiguous authorship have received close academic review ${ }^{78}$ and have been the subject of

\footnotetext{
77 Commission, 'Communication on establishing a new Partnership Framework with third countries under the European Agenda on Migration' COM(2016) 385 final, pp. 5-6

78 The EU-Turkey statement has been widely commented upon, ex multis see: Enzo Cannizzaro, Denialism as the Supreme Expression of Realism. A Quick Comment on NF v. European Council E Cannizzaro, European Papers, 2017 (2)1, 251; Thomas Spijkerboer, 'Bifurcation of Mobility, Bifurcation of Law. Externalization of Migration Policy Before the EU Court of Justice' (2018) 31 Journal of Refugee Studies 216-39; Gloria Fernández Arribas, 'The EU-Turkey Agreement: A Controversial Attempt at Patching up a Major Problem', European Papers 1(2016) 3, pp. 1097-1104; Olivier Corten, Marianne Dony, 'Accord politique ou juridique: quelle est la nature du "machin" conclu entre l'UE et la Turquie en matière d'asile?' (EU Migration Law blog, 10 February 2016) <https://eumigrationlawblog.eu/accord-politique-ou-juridique-quelle-est-lanature-du-machin-conclu-entre-lue-et-la-turquie-en-matiere-dasile/> accessed 1 July 2020; Jean-Baptiste Farcy, 'EU-Turkey agreement: solving the EU asylum crisis or creating a new Calais in Bodrum?' (EU Migration Law Blog, 7 December 2015); Jean-Baptiste Farcy, Geraldine Renaudière, 'L'accord UE-Turquie devant le Tribunal de l'Union européenne : Une incompétence lourde de conséquences?' (Cahier de l'EDEM, mars 2017)

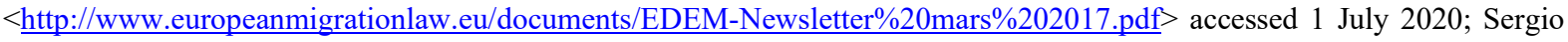
Carrera and Elspeth Guild, 'EU-Turkey plan for handling refugees is fraught with legal and procedural challenges' (CEPS Commentary, 2016)

<www.ceps.eu/ceps-publications/eu-turkey-plan-handling-refugees-fraught-legal-and-procedural-challenges/>
} 
decisions from the Court of Justice of the European Union. ${ }^{79}$ The content of the agreement is well known:

\section{'All new irregular migrants crossing from Turkey into Greek islands from 20}

March 2015 will be returned to Turkey. [...] 'For every Syrian being returned

to Turkey from Greek islands, another Syrian will be resettled to the EU, ${ }^{80}$

The Court decided that the EU-Turkey statement cannot be regarded as an act of the European Council. Moreover, the statement is not an international agreement and it did not require the formalities prescribed by EU and international law for its conclusion. This way of conceiving law-making, far from the clarity and certainty typical of law, can become an instrument at the service of political priorities, such as halting irregular arrivals of refugees and other migrants to the European Union. ${ }^{81}$ However, in the statement, it is assured that the return of irregular migrants to Turkey 'will take place in full accordance with European and International law'.

Other informal EU instruments and arrangements in the field of return are non-binding agreements deemed 'operational' and 'effective'. ${ }^{82}$ As such, they do not create rights and obligations under international law and they can be seen as 'soft versions' of readmission agreements. ${ }^{83}$ Despite the fact that there are no EU readmission agreements in place with third

accessed 1 July 2020; Steve Peers, 'The final EU/Turkey refugee deal: a legal assessment' (EU Law Analysis, 18 March 2016) $<$ http:/eulawanalysis.blogspot.com/2016/03/the-final-euturkey-refugee-deal-legal.html> accessed 1 July 2020; Mauro Gatti, 'The EU-Turkey Statement: A Treaty That Violates Democracy' (EJIL:Talk!, 18 April 2016) EJIL; Henri Labayle and Philippe de Bruycker, 'The EU-Turkey Agreement on migration and asylum: False pretences or a fool's bargain?' (EU Migration Law blog, 1 April 2016) <https://eumigrationlawblog.eu/the-eu-turkey-agreement-on-migration-and-asylum-false-pretences-or-afools-bargain/> accessed 1 July 2020.

${ }^{79}$ Case T-193/16 NG v European Council [2017] EU:T:2017:129 and Joined Cases C-208/17 P and C-210/17 P NF, NG and $N M$ [2018] EU:C:2018:705.

${ }^{80}$ EU-Tukey Statement, European Council press release of 18 March 2016.

${ }^{81}$ Massimo Starita linked the concept of 'hazard' to law and described how the hazard - and the CJEU - has been gradually recognising a role to hazard in the interpretation of law, thus undermining the principle primacy of law: Massimo Starita, 'Le hasard dans le droit de l'Union européenne en matière d'accès au territoire de l'Union', Revue trimestrielle de droit européen' (2019), pp. 43-54.

${ }^{82}$ Jean-Pierre Cassarino refers to those as 'EU-wide non-standard arrangements'. See, for instance: 'Informalizing the EU Readmission Policy', in A. Ripoll Servent, F. Trauner (eds), Routledge Handbook of Justice and Home Affairs Research, (Routledge, London 2018), p. 83; Peter Slominski and Florian Trauner, 'How do Member States Return Unwanted Migrants? The Strategic (non-)use of Europe during the Migration Crisis' Journal of Common Market Studies (2018) p. 101.

${ }^{83}$ Here 'soft' means the replacement of legal instruments by non-legal tools. E.g. the Joint Way Forward on migration issues between Afghanistan and the EU European Union and the Islamic Republic of Afghanistan, 'Joint Way Forward on migration issues between Afghanistan and the EU and Commission, 'Commission Decision of 8 September 2017 on the Signature of the EU-Bangladesh Standard Operating Procedures for the Identification and Return of Persons Without an Authorisation to Stay' ST 120312017 COR 1. 
countries and, therefore, no purely legal cooperation, return operations can be the object of intense informal cooperation between the EU and third countries. ${ }^{84}$

The Commission publishes the results of the migration compact negotiations as well as information about their implementation in documents called 'Progress Reports'. ${ }^{85}$ For instance, return operation with Ethiopia are at the core of a 'pilot project'. In the 'next step' section of the fourth progress report on the Partnership Framework with third countries, it can be read that one of the priorities of the EU in its informal cooperation with Ethiopia is '(to) Ensure a rapid delivery of travel documents by the Ethiopian consulates and effective return of the migrants concerned by the pilot project. ${ }^{96}$ The need to implement identification missions by third-country authorities on European territory is often reiterated in discussions during informal meetings. ${ }^{87}$

Member States also conclude informal arrangements linked to readmission, such as police cooperation agreements, agreements for technical cooperation, Standard Operating Procedures and Memoranda of Understanding. For instance, an informal bilateral agreement on readmission is the Memorandum of Understanding between Italy and Sudan, ${ }^{88}$ whose text was kept secret until it was accidentally revealed. ${ }^{89}$

\footnotetext{
${ }^{84}$ Notwithstanding their nature, they contribute to the objective of increasing returns and their legitimation is to be found in the Action Plan on Return, which is also a political document.

${ }^{85}$ Commission, 'First Progress Report on the Partnership Framework with third countries under the European Agenda on Migration' $\operatorname{COM(2016)} 700$ final; 'Second Progress Report: First Deliverables on the Partnership Framework with third countries under the European Agenda on Migration' $\operatorname{COM}(2016) 960$ final; 'Third Progress Report on the Partnership Framework with third countries under the European Agenda on Migration' COM(2017) 205 final; 'Fourth Progress Report on the Partnership Framework with third countries under the European Agenda on Migration' COM(2017) 350 final. Fifth Progress Report on the Partnership Framework with third countries under the European Agenda on Migration COM(2017)471 final.

${ }^{86}$ Commission, Fourth Progress Report on the Partnership Framework with third countries under the European Agenda on Migration COM/2016/0960 final, p. 8 .

${ }^{87}$ For instance, for the case of Nigeria, see Commission, Fifth Progress Report on the Partnership Framework with third countries under the European Agenda on Migration COM(2017)471 final, p. 4: "Regrettably, it has proven difficult to set a date for the second round of negotiations on the EU-Nigeria readmission agreement. It is important that the negotiations on the possible agreement, including on flanking measures to facilitate voluntary returns and socio-economic integration of migrants in their home communities, resume as soon as possible with the aim to reach agreement ahead of the next high-level political dialogue."

${ }^{88}$ Memorandum of Understanding between the Public Security department of the Italian Interior Ministry and the National Police of the Sudanese Interior ministry for the fight against criminality, management of frontiers and migration flows and about repatriation, signed in Rome on 2 August 2016.

${ }^{89}$ For a comprehensive appraisal of bilateral agreements linked to readmission, see: Mariagiulia Giuffré, The Readmission of Asylum Seekers under International Law (Hart Publishing, 2020).
} 
The latest reform of Frontex conferred to the agency the mandate of supporting and cooperating with EU Member States on return, which became a priority of the new regulation. ${ }^{90}$

Last but not least, the International Organization for Migration (IOM) manages the emergency Voluntary Humanitarian Return operation, aimed at returning migrants from Libya to their countries of origin, and strongly supported by EU funding and political action, such as the Joint Trilateral Task force on migration and Libya. ${ }^{91}$

Following unsuccessful negotiations of new EU readmission agreements in the last years, the EU has opted for alternative, simplified forms of cooperation with third countries. In this field, hard law seems unpopular and soft law is on the rise. Powers are increasingly delegated to EU and international agencies for return operations as well as border controls purposes.

\subsubsection{Border controls in third countries}

Border control is one of the key objectives of the EU external action on migration. It is achieved in two ways: with a dedicated EU agency and through delegation of powers to nonEU agencies, such as the IOM. Both actors contribute to build border control capacity of third country law enforcers and border coast guards, who will act on behalf of EU Member States to contain the mobility of entire populations.

From a legal perspective, Frontex has undergone an unrivalled evolution..$^{92}$ On the one hand, the Agency is the example of one of the few areas - migration and security - in which European migration law-making is inflating; on the other hand, Frontex embodies an aspect of informalization of legal activities, which can be understood as giving political discretion to agencies without making them fully accountable for their operations. ${ }^{93}$ In others words, while

\footnotetext{
${ }^{90}$ Regulation (EU) 2019/1896 of 13 November 2019 on the European Border and Coast Guard, OJ L 295, 14 November 2019, p. 1 , Art. $10 \S 1 \mathrm{n}$ ). For a discussion on this point see: Segolene Barbou Des Places, 'Frontex troisème version: grand pouvoirs... mais grandes responsabilité?’ Revue trimestrielle de droit européen (Dalloz 2020) pp. 131-136.

${ }^{91}$ On the topic, Francesco Luigi Gatta, The trilateral cooperation between the African Union, the European Union and the United Nations on migration and Libya: a successful example of collaboration?, Federalismi, Focus Africa (2019)3.

${ }^{92}$ The European Border and Coast Guard Agency (Frontex) is governed by Regulation (EU) 2019/1896 of 13 November 2019 on the European Border and Coast Guard, OJ L 295, 14 November 2019, p. 1. It was created in 2004 (Council Regulation (EC) No 2007/2004 of 26 October 2004 establishing a European Agency for the Management of Operational Cooperation at the External Borders of the Member States of the European Union, OJ L 349, 25.11.2004, p. 1-11), reformed in 2016 and again 2019.

${ }^{93}$ For an appraisal of challenges related to Frontex activities, Melanie Fink, Frontex and Human Rights: Responsibility in 'Multi-Actor Situations' under the ECHR and EU Public Liability Law, Oxford University Press, 2018; Jorrit Rijpma, 'External Migration and Asylum Management: Accountability for Executive Action Outside EU-Territory’ European Papers, 2(2017)2, pp. 571-596
} 
more law is needed to provide Frontex with further discretion and means, thus legitimatizing its actions, less law and legal safeguards are guaranteed when Frontex does act. ${ }^{94}$

International migration cooperation performed by Frontex, thanks to its soft nature, is often downplayed to be purely administrative cooperation. ${ }^{95}$ By way of example, Frontex has the prerogative of concluding Working Arrangements with third countries, ${ }^{96}$ which are not considered international agreements, despite being the result of a heavy political activity with consequences on individuals' fundamental rights. ${ }^{97}$ The text of each agreement states:

'The present Working Arrangement shall not be considered as an international treaty. Practical implementation of its contents shall not be regarded as fulfilment of international obligations by the European Union and its Institutions' ${ }^{98}$

However, the 'practical implementation' of a Frontex Working Arrangement is an activity full of legal implications. ${ }^{99}$ This is the same for Frontex liaison officers which are deployed in a third country and 'collect information and assists a third country in preventing illegal migration flows and support border management at the EU's external borders'. ${ }^{100}$

Recently signed Status agreements, which adhere to legal procedures for the conclusion of international treaties, are concluded between the EU and Eastern European countries. ${ }^{101}$

\footnotetext{
94 Melanie Fink, 'Frontex Working Arrangements: Legitimacy and Human Rights Concerns Regarding 'Technical Relationships' Merkurious, 28(2017)75, pp. 20-35.

${ }^{95}$ For an appraisal in the context of instruments aimed at implementing the Union Pre-Accession and Neighborhood policies and their effects on third countries and their citizens: Ilaria Vianello, 'Upholding a Principled Approach to the Use of EU Administrative Activities Externally: What Role for the Court of Justice of the European Union?' Yearbook of European Law, 37(2018)1, pp. 551-568.

${ }^{96}$ Frontex has concluded working arrangements with the authorities of 18 countries: Albania, Armenia, Azerbaijan, Belarus, Bosnia and Herzegovina, Canada, Cape Verde, the former Yugoslav Republic of Macedonia, Georgia, Kosovo*, Moldova, Montenegro, Nigeria, the Russian Federation, Serbia, Turkey, Ukraine and the United States.

${ }^{97}$ For a discussion of soft law and European agencies: Jacopo Alberti, 'L'utilisation d'actes de soft-law par les agences de l'Union européenne' Revue de l'Union européenne (2014) 576, pp. 161-169.

${ }^{98}$ Working Arrangement establishing operational cooperation between the Frontex and the Ministry of Interior of the Republic of Albania establishing operational cooperation between Frontex and the Ministry of Interior of Republic of Albania, done in Tirana, 19 February 2009, point 7 "Legal Status".

${ }^{99}$ Lilian Tsourdi, 'Beyond the 'migration crisis': three key challenges for Frontex and EASO', 2020, (UM Law Blog, 11 February 2020)

$<$ https://www.maastrichtuniversity.nl/blog/2020/02/beyond-'migration-crisis'-three-key-challenges-frontex-and-easo $>$ accessed 2 July 2020.

${ }^{100}$ Regulation (EU) 2019/1240 of the European Parliament and of the Council of 20 June 2019 on the creation of a European network of immigration liaison officers PE/50/2019/REV/1 OJ L 198, 25.7.2019, p. 88-104

${ }^{101}$ Status agreements have been signed with Albania in October 2018 (Status Agreement between the European Union and the Republic of Albania on actions carried out by the European Border and Coast Guard Agency in the Republic of Albania, OJ L 46, 18 February 2019, pp. 3-10) and Montenegro in October 2019 (Status Agreement between the European Union and Montenegro on actions carried out by the European Border and Coast Guard Agency in Montenegro, OJ L 173, 3 June 2020, p. 3-11) and Serbia (Status Agreement between the European Union and the Republic of Serbia on actions carried out by the
} 
They allow Frontex to launch joint operations on the territory of a neighboring country and to enjoy executive powers in their territory.

EU Member States are also increasingly delegating power to UN agencies, such as the IOM, which enjoy an important amount of discretion in how to exercise such powers. ${ }^{102}$ When cooperation is classified as merely 'technical', this reference is meant to neutralize its political and discretionary charge and to hide its true content by escaping formalities. ${ }^{103}$ Border patrols performed on behalf of the European Union by the Niger authorities, who receive training and equipment from the European Union itself, have huge repercussions on migrants' fundamental rights. ${ }^{104}$ Similarly, cooperation between EU and the Libyan Border and Coast Guard is currently at the center of judicial proceedings. ${ }^{105}$

On the one hand, border controls in the European Union are regulated by one of the most formalized regimes worldwide: the Schengen border code, ${ }^{106}$ the EU Visa code ${ }^{107}$ and the Carrier sanctions directive ${ }^{108}$ are the three main instruments of hard law in this field. The use of technology, databases and information exchange for security purposes complements border control functions through the digital surveillance of citizens and non-citizens mobility. ${ }^{109}$ The EU Agency Frontex, together with Member States, 'ensure safe and well-functioning external

\footnotetext{
European Border and Coast Guard Agency in the Republic of Serbia, OJ L 202, 25 June 2020, pp. 3-15). Similar status agreements have also been initialled with Serbia, North Macedonia (July 2018) and Bosnia and Herzegovina (January 2019) and are pending finalisation.

102 Julia van Dessel, 'International Delegation and Agency in the Externalization Process of EU Migration and Asylum Policy: The Role of the IOM and the UNHCR in Niger' (2019) 21 European Journal of Migration and Law, pp. 435-458

${ }^{103}$ E.g.: in the case of return cooperation, through activities such as the identification of aliens, their removal, the circumstances of interviews, the use of personal data, etc.

${ }^{104}$ Although with regards to the EU-Turkey statement, Van Malleghem reflected on the circumvention of European law and the "exploitation" of the European institutions outside the Union formal legal framework and therefore to the detriment of fundamental rights protection: Pieter-Augustijn Van Malleghem, 'La Cour de justice refuse de revisiter la légalité de l'accord UE-Turquie', Cahiers de l'EDEM, October 2018.

105 A case is currently pending at the European Court of Human Rights, SS and Others $v$ Italy, App no 21660/18. The application was introduced on 3 May 2018 and was communicated to the Italian government on 26 June 2019.For an appraisal of the legal implication of EU-Libya cooperation: Violeta Moreno Lax, 'The Architecture of Functional Jurisdiction: Unpacking Contactless Control-On Public Powers, S.S. and Others v. Italy, and the "Operational Model", German Law Journal, 21 (2020) 3, pp. 385-416. See also the Council of Europe Commissioner for Human Rights, 'Lives saved. Protected rights. Bridging the protection gap for refugees and migrants in the Mediterranean', Recommendation of 18 June 2019.

${ }^{106}$ Regulation (EU) 2016/399 of the European Parliament and of the Council of 9 March 2016 on a Union Code on the rules governing the movement of persons across borders (Schengen Borders Code) (codification), OJ, 23 March 2016, L 77/1.

${ }^{107}$ Regulation (EC) No 810/2009 of the European Parliament and of the Council of 13 July 2009 establishing a Community Code on Visas (Visa Code) (Consolidated text).

${ }^{108}$ Council Directive 2001/51/EC of 28 June 2001 supplementing the provisions of Article 26 of the Convention implementing the Schengen Agreement of 14 June 1985.

${ }^{109}$ For a discussion on interoperability of databases see: Niovi Vavoula, 'Interoperability of European Centralised Databases: Another Nail in the Coffin of Third-Country Nationals' Privacy?' (EU Migration Law blog, 8 July 2019).
} 
borders providing security'. ${ }^{110}$ Next to this body of legislation and its technical arrangements, border controls function have undergone several transformations, that range from temporal to spatial to physical changes and changes related both to the actors who perform border checks and to the subject who are target of border controls. ${ }^{111}$ Soft law intervenes when border controls are performed beyond the physical borders of the EU, before the prospective migrant has reach the EU territory or she is conceiving a migratory project and increasingly include the participation of non-state and private actors. ${ }^{112}$

\subsubsection{International protection, resettlement and third country asylum 'capacity'}

A third important area of informal cooperation with third countries is international protection and access to asylum.

First, the EU cooperates with third countries for the selection of refugees eligible for entering the European Union territory through humanitarian admission programs, including resettlement It must be recalled that EU resettlement schemes have, until now, been voluntary schemes and, therefore, are also forms of soft cooperation among EU Member States and with third countries which host large number of refugees. The European Commission has attempted to transform resettlement into a structured, permanent and legally binding mechanism integrated in the EU legal framework, although with scarce success. ${ }^{113}$

Humanitarian admission programs are usually implemented in cooperation with the United Nations High Commissioner for Refugees (UNHCR) in third countries. ${ }^{114}$ The UNHCR is assisting the EU with such tasks, mainly with Refugee Status Determination and, in particular, resettlement. The example of the emergency Transit Evacuation Mechanism in

\footnotetext{
110 This is the mission statement of the European Border and Coast Guard Agency (known as Frontex), available at www.frontex.europa.eu.

${ }^{111}$ Valsamis Mitsilegas, 'The Border Abroad, Within and Beyond A Rule-of-Law Based Deconstruction', in P. Minderhoud, S. Mantu \& K. Zwaan (eds), Caught in Between Borders: Citizens, migrants and humans. Liber Amicorum in Honour of prof. dr. Elspeth Guild (Wolf Legal Publishers, Tilburg 2019), pp. 41-48.

112 Violeta Moreno-Lax, V. and Martin Lemberg-Pedersen, 'Border-induced displacement: The ethical and legal implications of distance-creation through externalization', Questions of International Law, 56(2019)1, pp. 5-33

${ }^{113}$ Commission, 'Proposal for a regulation establishing a Union Resettlement Framework and amending Regulation (EU) No 516/2014 of the European Parliament and the Council' COM(2016) 468 final. The EU has invested financially and politically in embedding resettlement into its asylum policy. Since 2015, multiple ad hoc joint resettlement programmes have been adopted. On 13 July 2016, the Commission proposed a Union resettlement framework establishing a common set of standard procedures for selecting candidates for resettlement and a common protection status for resettled persons in the EU. A new pledging exercise has been launched for the resettlement of 50,000 refugees by October 2019.

${ }^{114}$ For a broader reflection on the extent to which policy controversies on humanitarian admission to Europe are channelled and managed through law see the book: Marie-Claire Foblet, Luc Leboeuf (Eds.), Humanitarian Admission to Europe: The Law Between Promises and Constraints (Nomos/Hart, Baden-Baden/Oxford, 2020).
} 
Niger is emblematic of the role played by UN agency in supporting the EU. The mechanism targets individuals evacuated from Libya, unable to return to their countries of origin. ${ }^{115}$

Next to humanitarian admission programs run by the EU or MS governments, civil society organizations have also taken part in refugee admission to the EU through pilot projects and programs such as the humanitarian corridors. ${ }^{116}$ Even in this case, a highly informalized structure of cooperation is apparent and allows civil society organizations (private actors) to take on shares of asylum responsibilities. ${ }^{117}$

Second, the EU deploys funding and resources to reinforce asylum capacity in third countries (following the so-called 'building protection elsewhere' narrative). ${ }^{118}$ For example, this can be done through the adoption of asylum implementing legislation by a third country which it will later justify the decision of a EU Member States to return there an asylum seeker. ${ }^{119}$

The objective of fostering international protection is two-fold. On the one hand, the EU contributes to the development of asylum systems in countries of transit (e.g. Turkey, Morocco, Tunisia). One of the objectives of the EU-Turkey statement is to contain Syrian refugees in Turkey. Cooperation between the EU and Ethiopia under the Migration Compact framework includes the support of 'the creation of industrial parks where jobs will be provided for refugees'. ${ }^{120}$ Once some capacity is put in place, ${ }^{121}$ the third country can be considered safe for the purpose of return. ${ }^{122}$

\footnotetext{
115 Those who are able to return to their home countries are assisted by the IOM, as explained in the 'return and readmission' section of this paper.

${ }^{116}$ Katia Bianchini, Humanitarian Admission to Italy through Humanitarian Visas and Corridors, in Marie-Claire Foblet, Luc Leboeuf (Eds.) Humanitarian Admission to Europe: The Law Between Promises and Constraints (Nomos/Hart, BadenBaden/Oxford, 2020) pp. $158-195$.

117 What is emerging from these new practices is that roles traditionally performed by state governments or international organisations are now taken on by private actors. For an analysis see: Eleonora Frasca, Private Sponsorship Programmes in Europe and the Rule of Law: Towards a Greater Involvement of Private Actors in International Protection (ADiM Blog, March 2020)<http://www.adimblog.com/2020/03/11/private-sponsorship-programmes-in-europe-and-the-rule-of-law-towards-agreater-involvement-of-private-actors-in-international-protection/> accesses 1 July 2020.

${ }_{118}$ Michelle Foster, 'Protection Elsewhere: The Legal Implications of Requiring Refugees to Seek Protection in Another State' 28 MICH. J. INT'L L. 223 (2007).

${ }^{119}$ Cathryn Costello, 'Safe Country? Says Who?' International Journal of Refugee Law 28 (2016) 4 pp. 601-22.

${ }^{120}$ Commission, Ethiopia: action and progress under the Migration Partnership Framework (June 2016 - June 2017), Factsheet.

${ }^{121}$ For instance, only by passing a law on asylum or by taking part into a Regional Development and Protection Programmes.

${ }^{122}$ For a discussion of "safe third country" notion and its related concepts see: Javier González Vega, 'Non-refoulement at risk? Asylums disconnection mechanisms in recent EU practice', Sergio Carrera, Juan Santos Vara and Tineke Stirk (2019). Constitutionalising the External Dimensions of EU Migration Policies in Times of Crisis, in: Legality, Rule of Law and Fundamental Rights Reconsidered (Edwar Elgar Publishing, 2019) pp. 75-94.
} 
Conversely, to overcome long lasting controversies over Search and Rescue in the Mediterranean and responsibilities for asylum applications of irregular migrants arriving to the EU by sea, proposals for establishing 'regional disembarkation platforms' in third countries are periodically advanced at the EU level. This is despite their lack of feasibility and the enormous consequences, from a legal perspective, that such arrangements might have. ${ }^{123}$

While internally to the EU, asylum law has been developed and harmonized into hard law, externally, the EU fails to formalize into hard law its commitments in light of the principle of asylum responsibility sharing with third countries and among Member States. ${ }^{124}$ Cooperation on asylum with third countries is left to soft forms of interaction, often driven by EU priorities to the detriment of refugees and asylum seekers right to seek protection to the EU. The soft law trend revels the difficulties in adopting hard law and achieving consensus within the EU Member States.

\subsection{A matter of funding: money in exchange for migrant containment in third countries}

None of this soft cooperation would be possible if it were not accompanied by a considerable deployment of funding. Cynical as it may seem, money is 'invested' by the EU into third countries in exchange of migrant containment and migration prevention.

While EU Official Development Aid (ODA) has been increasingly used as a response to the migration 'crisis' through the geographical re-allocation of aid, new emergency external financial instruments have emerged. Various EU trust funds (EUTFs) have been created: the EU Trust Fund for the Central African Republic, ${ }^{125}$ the EU Regional Trust Fund in Response to the Syrian Crisis, ${ }^{126}$ the European Union Emergency Trust Fund for stability and addressing root causes of irregular migration and displaced persons in Africa (EUTFA) and the Facility

\footnotetext{
${ }^{123}$ For a legal analysis, see Marco Fantinato, 'EU Regional Disembarkation Arrangements in the Mediterranean: Between the Outsourcing of Search and Rescue Services and the Externalisation of Sea Border Management' The Italian Yearbook of International Law (2018)1, pp. 63-76; Francesco Maiani, “"Regional Disembarkation Platforms" and "Controlled Centers": Lifting the Drawbridge, Reaching out Across The Mediterranean, or Going Nowhere?' (RefLaw, 14 September 2018), $<\underline{\text { http://www.reflaw.org/regional-disembarkation-platforms-and-controlled-centres-lifting-the-drawbridge-reaching-out- }}$ across-the-mediterranean-or-going-nowhere/>, accessed 1 July 2020.

${ }^{124}$ Tineke Stirk, 'Migration deals and responsibility sharing: can the two go together?', Constitutionalising the External Dimensions of EU Migration Policies in Times of Crisis, in: Legality, Rule of Law and Fundamental Rights Reconsidered (Edwar Elgar Publishing, 2019) pp. 75-94.

${ }^{125}$ Known as the 'Bêkou Trust Fund', Commission Decision of 11 July 2014 on the Establishment of a European Union for the Central African Republic, C(2014) 5019, Brussels.

${ }^{126}$ Known as the 'Madad Fund', Commission Decision of 21 December 2015 Amending Decision C(2014) 9615 Final on the Establishment of a European Union Regional Trust Fund in Response to the Syrian Crisis, C(2015) 9691, Brussels.
} 
for Refugees in Turkey. ${ }^{127}$ The underlying objective of these instruments of the European action on migration in third countries is containing migration. ${ }^{128}$

For the purpose of a 'more or less law' discussion it could be argued that the set-up of EU Trust Funds follows a less hard law logic. Indeed, EU Trust funds are established through a constitutive agreements between the European Commission and the donors for situations of emergency, post-emergency and for thematic actions that are deemed necessary to react to a crisis. ${ }^{129}$ They disregard EU rigid budgetary rules and they re-introduce inter-governmental dynamics, while the European Parliament only has a right to scrutiny over the Trust Fund constitutive agreement. As compared to other EU funding instruments, the EU Trust Fund follow more flexible and less bureaucratic rules and are provided with a different Commissiondriven management structure. ${ }^{130}$

Trust funds are only established and implemented if there is added value of the Union intervention (scale or potential effects better achieved at the EU level), when the use of the existing financing instruments is not sufficient to achieve EU policy objectives, if they bring clear political visibility for the EU and managerial advantages as well as better control of donors' contributions. For instance, considered to be the implementing branch of the EUTFA, programs under the EUTFA consist of joint commitments and concessions between the EU (so-called 'action projects') and third countries and are implemented in twenty-six partner countries across three regions of Africa: the Sahel and Lake Chad, the Horn of Africa and North Africa.

The legality and the effectiveness of the EUTFA have been questioned by scholars, civil society and EU institutions such as the European Parliament ${ }^{131}$ and the European Court of Auditors. ${ }^{132}$ The geographical scope of the Trust Fund makes it doubtful that there is

\footnotetext{
${ }^{127}$ Commission, Decision of 24 November 2015 on the coordination of the actions of the Union and of the Member States through a Coordination Mechanism - the Refugee Facility for Turkey - Strasbourg, C(2015) 9500 Final. The EU committed a total of EUR 6 billion to support refugees in Turkey.

${ }^{128}$ Commission, Decision of 20 October 2015 on the establishment of a European Union Emergency Trust Fund for stability and addressing root causes of irregular migration and displaced persons in Africa, Brussels, 20 October 2015 C(2015) 7293 final. Programmes financed under the EUTFA are implemented in twenty-six partner countries across three regions of Africa: the Sahel and Lake Chad, the Horn of Africa and North Africa for a total of EUR 318230000.

${ }^{129}$ According to Articles 187 and 259 of the Financial Regulation 966/2012.

${ }^{130}$ Heliodoro Temprano Arroyo, Using EU Aid to Address the Root Causes of Migration and Refugee Flows (European University Institute, Migration Policy Centre, 2019)

${ }^{131}$ European Parliament, 'Oversight and Management of the EU Trust Funds Democratic Accountability Challenges and Promising Practices’ (Budgetary Affairs, Brussels (C) European Union, 2018).

${ }^{132}$ European Court of Auditors, European Union Emergency Trust Fund for Africa: Flexible but lacking focus, Special Report, European Union, 2018. Three Italian organisations recently filed a complaint before the European Court of Auditors in which
} 
currently an 'emergency or post emergency situation' in entire regions of Africa and the process of selection of action projects is deemed opaque and informal. It raises issues in terms of transparency and clarity over eligibility and selection criteria because of the lack of open competition. ${ }^{133}$

Overall, the use of emergency funding for the external action on migration corresponds to a less hard law trend and it reinforces the preference for soft law: policy documents are used to justify funding instruments adopted through extra-budget structures. ${ }^{134}$

\subsection{A matter of language: the narrative on EU third country migration cooperation}

The European Commission has conveyed a certain 'political culture' of migration, portrayed as an invasion of desperate people fleeing poverty and conflict, perpetuating the migration crisis narrative, and thus supporting the blurring of policy and law. It is particularly in policy documents that it is suggested 'to use tools to their full potential', ${ }^{135}$ 'finding solutions that cater for all needs and using all leverages and tools" ${ }^{136}$ or 'to take advantage of all the tools available'. ${ }^{137}$ The EU institutions everyday language is responsible, for the large part, of diffusing soft cooperation: Migration Compacts are 'launched' by high level visits of the EU Commissioner for Migration, political dialogues 'start', they are followed by 'technical missions' and a series of measures are therefore implemented.

Another aspect related to the narrative around soft cooperation is the so-called 'conditionality' or the 'more-for-more' approach. The Commission affirmed that:

'A mix of positive and negative incentives will be integrated into the EU'S development and trade policies to reward those countries willing to cooperate

\footnotetext{
they call the European Union to "suspend funding to the program through which migrants are blocked in Libya, because it violates EU financing law regulations and international regulations on human rights."

${ }^{133}$ For a discussion, see Thomas Spijkerboer and Elies Steyger, 'European External Migration Funds and Public Procurement Law', in European Papers 4(2019):2, pp. 493-521.

${ }^{134}$ European Parliament, Oversight and Management of the EU Trust Funds Democratic Accountability Challenges and Promising Practices, p. 71.

${ }^{135}$ Commission, 'Contribution to the European Council Managing migration in all its aspects: progress under the European Agenda on Migration', Brussels, 4. December 2018 COM(2018) 798 final, p. 10.

${ }^{136}$ Ibidem.

${ }^{137}$ Commission, 'Progress report on the Implementation of the European Agenda on Migration', Brussels, 6 March 2019 $\operatorname{COM}(2019) 126$ final, p. 12.
} 
effectively with the EU on migration management and ensure there are consequences for those who refuse'. ${ }^{138}$

An example is funding for development and the promise of legal mobility opportunities to third countries in exchange of stricter border controls (the case of Senegal), or refugee resettlement programs conditional on third country cooperation on return (the case of Niger). Assistance under the Facility for Refugees in Turkey is also conditional upon 'strict compliance by the Republic of Turkey with undertakings reflected in the EU-Turkey Joint Action Plan and the EU-Turkey Statement'. ${ }^{139}$

Further, the recent recast of the EU Visa Code, ${ }^{140}$ legalizes the informal trend to use visa policy as leverage for cooperation on readmission. It does so by making the conditions for issuing visa stricter for those countries which fail to cooperate with the EU on migration issues. $^{141}$

The language used to describe these alleged political activities is very distant from the rigor, clarity and legal certainty required by law for any Union action. Due to their non-legally binding character, activities that belong to soft cooperation are not subjected to publication obligations in the Official Journal of the EU, which drastically reduces access to information

\footnotetext{
138 Commission, 'Communication on establishing a new Partnership Framework with third countries under the European Agenda on Migration' COM(2016) 385 final, p. 5-6

${ }^{139}$ Common Understanding Establishing a Governance and Conditionality Framework for the Refugee Facility for Turkey, The 'Facility' between the European Commission and the EU Member States, Brussels, 2016, Art. 24.

${ }^{140}$ Regulation (EU) 2019/1155 of the European Parliament and of the Council of 20 June 2019 amending Regulation (EC) No 810/2009 establishing a Community Code on Visas (Visa Code) PE/29/2019/REV/1 [2019] OJ L 188 25-54.

${ }^{141}$ Article 25bis on 'cooperation with third countries', for instance, by increasing visa costs or the number of documents to provide, or by slowing down the visa application procedures. For an analysis see: Segolène Barbou Des Places, 'Le code des visas, nouveau « levier » de la politique d'éloignement des étrangers en situation irrégulière' Revue trimestrielle de droit européen (2020), pp. 127-131; Elspeth Guild, 'Amending the Visa Code: Collective Punishment of Visa Nationals?' (EU Migration Law, 10 May 2019) <https://eumigrationlawblog.eu/amending-the-visa-code-collective-punishment-of-visanationals/> accessed 3 July 2020; S. Peers, 'The revised EU visa code: controlling EU borders from a distance (EU Law Analysis, 17 April 2019) < http://eulawanalysis.blogspot.com/2019/04/the-revised-eu-visa-code-controlling-eu.html> accessed 3 July 2020.
} 
and democratic scrutiny. ${ }^{142}$ Lacking publicity and transparency, soft law, as a surrogate for legislation, becomes inscrutable and intangible 'cloud law'. ${ }^{143}$

For instance, information on the actions implemented under the EU Trust Fund for Africa are scattered through a series of documents (called 'action fiches'). The systematization of this information resembles a Russian doll way of 'packaging' key information into one document that will lead to another document that will lead to another document.

Just as beauty is in the eye of the beholder, the soundness of the legal interpretation of such statements - in principle, policy documents - is in the mind of the attentive reader. The combination of the information gathered might reveal, after careful scrutiny, that apparently neutral statements de facto create rights and obligations. Informal instruments do create rules that belong to the legal order of the EU, obligations between the EU and third countries, and their content might even impinge on migrants' fundamental rights.

This descriptive analysis shows that the widespread use of soft cooperation creates a 'grey area' between law and politics. In the short-term, non-legally binding measures have been justified through a discourse that belongs to emergency politics. In the long-term, this way of cooperation is becoming the new normal: a supposedly legitimate way of conceiving law-making in this field.

\section{European soft law theory: informal cooperation belongs to realm of soft law}

Soft cooperation can have the binding force of law, intended as the capacity to have a causal influence in bringing about a prescribed behavior. ${ }^{144}$ The reach of the European external action on migration, in the multiple forms that it can take, has a triple legal impact: first, on the EU legal order itself; second, on third countries' legal orders (both in their relationship with the EU and by themselves); and, third, on migrants' fundamental rights. This impact ranges

\footnotetext{
${ }^{142}$ Whilst in a case of bilateral cooperation between Italy and Tunisia, the European Court of Human Rights in the case of Khlaifia and others v. Italy, App no 16483/12 (ECtHR, Grand Chamber, 15 December 2016), has recognised the consequences of informal cooperation: "the Court would note at the outset that the full text of that agreement had not been made public. It was therefore not accessible to the applicants, who accordingly could not have foreseen the consequences of its application. Moreover, the press release published on the website of the Italian Ministry of the Interior on 6 April 2011 merely referred to a strengthening of the border controls and the possibility of the immediate return of Tunisian nationals through simplified procedures. It did not, however, contain any reference to the possibility of administrative detention or to the related procedures" $(\S 102)$.

${ }^{143}$ Sylvie Sarolea, Francesco Luigi Gatta, Eleonora Frasca, 'What could the Global Compact on Migration mean for Europe?, E. Desmet, T. Moonen, T. Ruys (Eds) Het Migratiepact: kroniek van een crisis (Die Keure, 2020), pp. 159-190.

${ }^{144}$ Kenneth W. Abbott and Duncan Sindal, 'Hard and Soft Law in International Governance' (2000) 54 International Organization 421.
} 
from introducing changes in domestic legislation, ${ }^{145}$ to building capacity of domestic law enforcers, to the exchange of classified information or personal data, and to participation in border control operations and return operations, and so on.

Reverting to soft law theory can help clarify the relationship between informal cooperation and EU law, an issue which stands, by nature, at the boundaries of law. Through time, different approaches to soft law, whose characteristics prevent the attribution of its origin to formal sources, have been developed by legal scholars. One traditional categorization is the binary vs continuum view. ${ }^{146}$ The first one consists of a firm rejection of soft law as not pertaining to the legal sphere on the assumption that normativity has no degrees. The second, more balanced view, considers normativity as 'gradual' and that norms can carry a variety of different impacts and legal effects. This second view is supported here.

In sensitive fields, it is more likely to revert to soft law because States want to avoid a loss of sovereignty represented by hard obligations. ${ }^{147}$ Not only is this true for Member States in their relationship with the EU, but it is especially true for third countries. From a Eurocentric perspective, scholars have rightly conceptualized the 'externalization' of migration controls and containment practices outside Europe, but it is rarely spoken of 'internalization' of border controls and other obligations related to migration by third countries. From the perspective of third countries, informal cooperation, especially if accompanied by a conspicuous amount of funding, motivates them to behave in compliance with the requirements of EU countries while, at the same time, not accepting hard obligations through fully-fledged international agreements. Such binding international agreements - especially in the field of return and readmission - would render them unpopular in the eyes of their nationals.

Another functional classification which became popular in European soft law theory is the distinction among 'pre-law', 'law-plus', and 'para-law'. ${ }^{148}$ According to this classification, soft law with pre-law functions consists of those acts which serve as an impulse for hard legislation. Looking at the above-mentioned examples, the soft instrument of a Mobility

\footnotetext{
${ }^{145}$ Thomas Spijkerboer, 'The New Borders of Empire. European migration policy and domestic passenger transport in Niger', in Minderhoud P, Mantu S \& Zwaan K (eds), Caught in Between Borders: Citizens, migrants and humans. Liber Amicorum in Honour of prof. dr. Elspeth Guild (Wolf Legal Publishers, Tilburg 2019) pp. 49-57

${ }^{146}$ Anne Peters and Isabella Pagotto, 'Soft Law as a New Mode of Governance: A Legal Perspective' [2006] SSRN Electronic Journal.

${ }^{147}$ Fabien Terpan, 'Soft Law in the European Union-The Changing Nature of EU Law: Soft Law in the European Union' (2015) 21 European Law Journal, pp. 68-96

${ }^{148}$ Linda Senden, Soft Law in European Community Law, Oxford/Portland, 2004, p. 121.
} 
Partnership - if it has led to the conclusion of an international agreement, such as an EURAhas absolved the role of 'pre-law'. ${ }^{149}$ Law-plus functions serve the objective of completing the interpretation of existing law. Soft return EU policy is an example of this function whereby soft law interacts with hard law: EU and national actors who implement the EU return directive are also bound by the reading of the directive in soft documents such as the EU Return Action Plan or the Return Handbook. ${ }^{150}$ Finally, soft law assumes a para-law function as a substitute for non-available hard law, because of divergencies of views on the desirability of hard law and its content. An example of this type of soft law is the Open Method of Coordination, an instrument of European Law, attempted to overcome Member States divergences without the intrusiveness of harmonization of law. If the EU and its MS are cautious to commit, because of the real or perceived uncertainty of a certain phenomenon that they would otherwise regulate, they revert to soft law.

When the Union promotes informal cooperation, the very legal framework (the Union competence to legislate) is disregarded. Instead, in order to achieve similar objectives, the EU is opting for alternative, simplified forms of cooperation, shaped to fit the concerned third country's migration 'profile' and its 'utility' in terms of migration control. The need to act 'urgently' is often provided as justification for the choice of non-legally binding measures, tailor-made solutions, and actions outside the scope of the legislative process or legal requirements. ${ }^{151}$

One the one hand, the European Union might be accused of acting ultra vires, if the division of competences is taken seriously and if, in the field of shared competence, the EU must exercise its powers in strict observance of formal rules and within the Treaties formal boundaries. ${ }^{152}$ Conversely, this increasing resort to soft law might be interpreted as the capacity of the European Union of producing legal effects beyond formal boundaries in name

\footnotetext{
${ }^{149}$ Stefan Brocza1, Katharina Paulhart, 'EU mobility partnerships: a smart instrument for the externalization of migration control' European Journal of Futures Research (2015)3, p. 15; Fanny Tittel-Mosser, 'The Unintended Legal and Policy Relevance of EU Mobility Partnerships', European Journal of Migration and Law, 20(2018)3, pp. 314-337.

150 Peter Slominski, Florian Trauner, 'Reforming Me Softly - How Soft Law Has Changed EU Return Policy since the Migration Crisis' (2020) West European Politics. According to the authors, the drawback of this kind of soft law is that, by exploiting legal gaps in hard, ambiguous law, it adds a new policy layer for its interpretation.

${ }^{151}$ Juan Santos Vara, 'Soft international agreements on migration cooperation with third countries: a challenge to democratic and judicial controls in the EU', Sergio Carrera, Juan Santos Vara and Tineke Stirk (2019). Constitutionalising the External Dimensions of EU Migration Policies in Times of Crisis: Legality, Rule of Law and Fundamental Rights Reconsidered (Edwar Elgar Publishing, 2019).

152 Paula García Andrade, The distribution of powers between EU Institutions for conducting external affairs through nonbinding instruments, European Papers, 1(2016)1, pp. 115-125
} 
of the effectiveness of its actions. This happens with the blessing of Member States which, in parallel, increasingly resort to soft law in their bilateral international relations with third countries. $^{153}$

The flagrant example of the EU-Turkey statement, with its unexpected judicial developments, resulted in the inadmissibility ruling by the Court of Justice of the European Union, and gives an indication of the high stakes related to informal cooperation. While the activity of the CJEU has contributed to further uniformity in the interpretation of European migration law internally, in the interpretation of the external dimension, the Court faces more challenges and less freedom. This has been identified as a 'constitutionalization deficit' of the external dimension which forces the Court of Justice to limit its judgment over the EU external action, a field extremely sensitive to institutional (un)balances between European institutions and shared competences between Member States and the Union. ${ }^{154}$

As presented in this paper, the various instruments that the EU deploys while cooperating with third countries on migration regardless of their primary apparent nature (political, financial, etc.), their all or symptoms of a EU preference for soft law as compared to hard law. As a general concept embracing a non-homogenous phenomenon, 'soft law' can be a useful tool to analyze the legal effects produced by this practice.

\section{Conclusion: the long terms effect of informal cooperation of European law-making}

If it is accepted that informal cooperation is soft law and that soft law pertains to the legal sphere, different issues arise: first, resorting to soft law creates semi-juridical spaces and procedures other than those proper to law (de-proceduralization); second, soft law evades the pre-defined, typical forms of acts, becoming inscrutable and intangible (de-formalization); third, soft law is elusive to both democratic and judicial control, and poses major obstacles as regard to the justiciability of this kind of cooperation (de-legalization).

\footnotetext{
153 See, for instance: Alessandra Algostino, 'L'esternalizzazione soft delle frontiere e il naufragio della Costituzione', Costituzionalismo.it, Le riforme di una democrazia costituzionale (2017) 1, pp. 139-182; Martino Reviglio della Veneria, 'Externalizing Migration Management through Soft Law: The Case of the Memorandum of Understanding between Libya and Italy' Global Jurist, 20(2019)1; Andrea Spagnolo, 'The Conclusion of Bilateral Agreements and Technical Arrangements for the Management of Migration Flows: An Overview of the Italian Practice’ The Italian Yearbook of International Law, 1(2018) pp. 209-230.

${ }^{154}$ Luc Leboeuf, 'La Cour de justice face aux dimensions externes de la politique commune de l'asile et de l'immigration. Un défaut de constitutionnalisation?', Jean-Yves Carlier (eds), La politique migratoire européenne à la lumière des jurisprudences relatives au visa humanitaire et à la déclaration UE-Turquie, RTD (2019), p. 55.
} 
Whereas, in principle, in order to produce hard law, EU institutions may only act in accordance with the principle of legality, European soft law creates semi-juridical spaces and procedures other than those formalized and rigid, proper to Union law (de-proceduralization). Only by respecting institutional procedures, and their corollary principles - subsidiarity and proportionality - legal certainty and the rule of law can be secured. ${ }^{155}$

In a field of shared competence such as migration, European law can only be produced following the rules stemming from the Treaty framework, where a legal basis confers as well as delimits powers; the CJEU ensures that such conferral and delimitation is adhered to. A European common immigration policy shall be achieved, in particular, through the ordinary legislative procedure, administrative cooperation between Member States ${ }^{156}$ and the conclusion of agreements with third countries. ${ }^{157}$

Regarding the conclusion of formal international agreements, EU international treatymaking powers in the field of migration are the result of the explicit conferral of external competence in the Treaty of Lisbon. Treaty-making powers are distributed in a manner which is respectful of the principle of sincere cooperation between the Member States and the EU, and the principle of institutional balance between EU institutions. ${ }^{158}$ Each institution operates within its own treaty powers, procedures and objectives and must cooperate with the others. When soft law arrangements are put in place, the remaining European institutions are therefore marginalized and the center of gravity of institutional pluralism drifts towards Member States (either by themselves, either acting through the Council) to the detriment of the other institutions, ${ }^{159}$ particularly the European Parliament. ${ }^{160}$

Secondly, while circumventing legislative procedures, soft law also circumvents the pre-defined, typical, forms of acts (de-formalization). It is appropriate to talk about forms because it is precisely by virtue of the soft form of these agreements that consequences are also

\footnotetext{
${ }^{155}$ Caterina Molinari, 'The EU and Its Perilous Journey Through the Migration Crisis: Informalisation of the EU Return Policy and Rule of Law Concerns' [2018] SSRN Electronic Journal < https://www.ssrn.com/abstract=3171983 $>$. one of the safeguards prescribed during the process of adoption of an international agreement between the European Union and third countries.
} 
produced regarding their content. The rigidity of legal forms is meant to support transparency, publicity, reason giving, and overall democratic accountability for the decisions taken. ${ }^{161}$

Due to their allegedly non-legally binding character, the text of those agreements is not published in the Official Journal of the EU and, in general, the content of such cooperation is difficult to ascertain. Access to information by citizens, in general, and by scholars and advocates, in particular, is drastically reduced. Any EU citizen has the fundamental right of access to documents of the European institutions, bodies, offices and agencies of the Union. ${ }^{162}$ The purpose of public access is the full accessibility of data and documents held by public authorities, in order to protect citizens rights, promoting their participation to administrative activity and enabling widespread forms of control over the pursuit of institutional functions and the use of public resources. This is irrespective of the legislative content of the documents.

Thirdly, the choice of an obscure, non-typical form of the act, which falls outside the legislative procedure, may subtract its content, on the one hand, from the wider democratic debate and, on the other hand, from judicial scrutiny (de-legalization). Both the form and content are on an equal level in respect of their importance, however the difficulty to supervise content derives from the preference of soft forms, opacity and secrecy. ${ }^{163}$

The CJEU power of judicial control, as witnessed by the EU-Turkey Statement case, can be precluded by informal measures adopted outside the European legal framework and which result in the Court's self-restraint or, according to some scholars, judicial passivism. ${ }^{164}$ Legal certainty as well as the protection of individual fundamental rights are negatively affected by the resort to soft law and by the contextual interpretation of its legal effects by Courts. ${ }^{165}$

\footnotetext{
${ }^{161}$ See for instance, on transparency of the EU-Turkey statement, the caselaw commentary of Caterina Molinari, 'The General Court's Judgments in the Cases Access Info Europe v. Commission (T-851/16 and T-852/16): A Transparency Paradox?' European Papers 3(2018), pp. 961-972.

162 This right is enshrined in Article 15 TEU and in Article 42 of the Charter of Fundamental Rights of the European Union.

${ }^{163}$ Louis Imbert, 'La coopération sans le(s) droit(s) : le foisonnement des accords « injusticiables » avec les pays tiers' (2017) 114 Plein droit, pp. 45-48

${ }^{164}$ Iris Goldner-Lang, 'Towards 'Judicial Passivism' in EU Migration and Asylum?' (EU Migration Law Blog, 24 January $2018)<\mathrm{https}$ ://eumigrationlawblog.eu/towards-judicial-passivism-in-eu-migration-and-asylum-law-preliminary-thoughtsfor-the-final-plenary-session-of-the-2018-odysseus-conference/> accessed 1 July 2020.

${ }^{165}$ For an appraisal of implication for refugee rights see: Moreno-Lax V and Giuffré M, 'The Rise of Consensual Containment: From “Contactless Control”' to "Contactless Responsibility" for Forced Migration Flows' S. Juss (ed.), Research Handbook on International Refugee Law (Edward Elgar, forthcoming).
} 
One might argue that no institution is as best placed as the CJEU to determine the validity, legitimacy, and effects of soft law. The Court can certainly be called to take a stance with regards to the surge of law-like instruments to which legal effects are artificially attributed. However, when it comes to the control that the CJEU exercises over soft law, the case law is ambiguous. ${ }^{166}$ It is also true that the case law on the external dimension of European migration law (and in general on the external aspects of the Area of Security Freedom and Justice) is quite limited.

These are some of the implications that the preference for soft law instruments in the field of third country cooperation on migration entails. The EU approach to cooperation with third countries exposes that 'less' hard law is preferred and substituted by soft law. A new 'law-minus' function of soft law emerges. ${ }^{167}$ By disregarding procedures for hard law as well as typical forms of the acts and by avoiding the justiciability of violations which might occur because of the content of soft cooperation, soft law does not represent a substitute for nonavailable hard law, but rather a poor copy of it.

\footnotetext{
${ }^{166}$ On the one hand, following the Grimaldi case (C-322/88), the Court has affirmed that national court are bound to take nonlegislative acts (in the case: recommendations) into consideration in order to resolve disputes submitted to them when they are relevant in interpreting the law. On the other hand, the European Court of Justice judicial review of soft law instruments has been limited and, according to scholars, unsatisfactorily from a constitutional perspective: the Court has showed reluctance in acknowledging the existence of binding effects of soft law. A comprehensive approach to soft law interpretation has been advanced by Advocate General Bobek in his opinion in the Belgium v. Commission case (C-16/16).

167 This is just a provocation adding to the work of Linda Senden.
} 